\title{
Patents and Other Intellectual Property Rights
}

\author{
GianCarlo Moschini
}

Working Paper 01-WP 275
May 2001

\section{Center for Agricultural and Rural Development lowa State University \\ Ames, lowa 50011-1070 \\ www.card.iastate.edu}

GianCarlo Moschini is professor of economics and Pioneer Hi-Bred International Chair in Science and Technology Policy, Department of Economics and Center for Agricultural and Rural

Development, lowa State University.

This article was prepared for inclusion in the Encyclopedia of Life Support Systems, a UNESCOsponsored project (http://www.eolss.co.uk/). The author acknowledges comments by N. Harl and L. Lorenzen on an earlier draft.

This publication is available online on the CARD website: $\underline{w w w . c a r d . i a s t a t e . e d u}$.

For questions or comments about the contents of this paper, please contact GianCarlo Moschini, 583 Heady Hall, lowa State University, Ames, IA 50011-1070; Ph: 515-294-5761; Fax: 515-2946336; E-mail: moschini@iastate.edu.

lowa State University does not discriminate on the basis of race, color, age, religion, national origin, sexual orientation, sex, marital status, disability, or status as a U.S. Vietnam Era Veteran. Any persons having inquiries concerning this may contact the Director of Affirmative Action, 318 Beardshear Hall, 515-294-7612. 


\begin{abstract}
This article reviews intellectual property rights (IPRs), with some emphasis on the protection of agricultural and life sciences innovations. The main institutional features of IPRs are first discussed, along with a brief historical background and an articulation of the main rationale for the existence of such rights. This is followed by an overview of the principal economic issues related to IPRs. The main benefit/cost trade-offs of allowing patents and other IPRs are explained, and specific issues are then analyzed in some depth, including the scope of patent protection, the effects of patent races, and the problems arising when IPRs concern cumulative and/or complementary innovations. The economics of IPRs are further illustrated by considering instruments alternative to patents, such as prizes and government procurement contracts. The article ends with a brief discussion of some open policy issues in this area.
\end{abstract}

Key Words: Efficiency, incentives, innovation, invention, market failure, monopoly, property rights, public good, second best. 


\section{PATENTS AND OTHER INTELLECTUAL PROPERTY RIGHTS}

\section{Introduction}

Property rights are well entrenched in the institutional setting of many societies, and we have come to consider them an integral part of capitalism and market-oriented economies. Intellectual property rights (IPRs) are special kinds of property rights defined over some intangible assets associated with human inventiveness and creativity. The economic rights individuals have on assets are conceptually distinct from associated legal rights, although economic rights are enhanced by the existence of an appropriate legal system that clearly defines such rights and improves enforcement. This is particularly relevant for IPRs, where the intangible nature of the assets involved means that the actual functioning of these rights owes much to the letter and practice of the law. Several distinct forms of IPRs have evolved over time to define and deal with various forms of property. But they all share the principle that innovators receive a priority or exclusivity in the economic exploitation of the product of their work.

The purpose of this article is to review some of the main issues surrounding IPRs. Although it is readily recognized that the analysis of IPRs gives rise to considerations that touch on many disciplines (including law, history, and moral philosophy), it is arguably the case that IPRs are meant, first and foremost, to address an economic problem. The present article, after a brief presentation of the institutional setting, will therefore focus on the economic implications of IPRs. In this age of seemingly unprecedented scientific and technological breakthroughs, it is of considerable interest to analyze the role that IPRs may play in bringing about innovations and economic growth.

\section{A Brief Taxonomy and History}

Patents, copyrights, trademarks, and trade secrets are the most common forms of IPRs, although related but distinct forms of intellectual protection have arisen to deal 
specifically with agricultural innovations. A patent is arguably the strongest form of IPR. It typically is issued by a government agency—in the United States, for example, the Patent and Trademark Office (PTO) - upon successful evaluation of an application. The patent confers to the inventor the sole right to exclude others from economically exploiting the innovation (by making it, using it, selling it, etc.) for a limited time (for most countries this time period is now 20 years from the date of filing).

To be patentable an innovation must be novel in the sense of not constituting part of the prior art or, more generally, of not being already in the public domain. In the United States it is possible for an idea to be novel and yet already published, provided the publication date is within one year of the filing date (the implementation of this "grace period" is feasible because of the somewhat unique U.S. first-to-invent principle for awarding patents, as opposed to the first-to-file criterion used virtually everywhere else). To be patentable, an innovation must also involve an inventive step, meaning that it must be nonobvious to a person with ordinary skills in the particular field of application. And, the innovation must be useful; that is, the innovation must permit the solution of a particular problem in at least an application. A major requirement of a patent application is "disclosure." That is, the patent application must describe the invention in sufficient detail to enable those skilled in the particular field to practice it. In so doing, the patent application also lays out specific claims as to the scope of the patent itself. In this context, a unique feature of U.S. patent law is the requirement that the best mode of practicing the invention be disclosed in the patent application.

The foregoing describes so-called utility patents, the most important and common kind. The subject matter of such patents encompasses machines, industrial processes, composition of matter, and articles of manufacture. Other patents that can be obtained in the United States are (industrial) design patents, utility model (petty) patents, and plant patents. Important kinds of scientific discoveries — such as laws of nature, natural phenomena, and abstract ideas-have traditionally been outside the statutory scope of patents. But recent developments in computer software, information technology, and biotechnology are challenging a constraining interpretation of such exclusions. 
Copyrights apply to original works of authorship. Examples illustrating the statutory domain of copyrights include books, photographs, sound recordings, motion pictures, and other artistic works in general. An explicit condition for such creative expressions to be protectable by copyrights is that they be fixed in a tangible medium (because copyrights protect the form of expression rather than the subject matter). Unlike patents, there is no novelty or usefulness requirement, although there are conditions of originality (the work has not been copied) and authorship. In the United States, works can be registered and deposited at the Copyrights Office, but property rights under the copyright statute exist independently of such a formality. Protection under the copyright statute in the United States extends for the lifetime of the owner plus 50 years.

A trademark is a sign, word, symbol, or device (which may include or combine letters, numbers, pictures, emblems, etc.) that distinguishes the goods or services of an enterprise from those of others. No novelty or originality is necessary, but the main requirement is distinctiveness (a mark cannot be a generic description). For trademarks to be valid, they typically have to be registered (in the United States, for example, with the PTO). Any unauthorized use of a mark identical (or confusingly similar) to a valid trademark is prohibited. Protection of trademarks does not have a time limit, provided the trademarks are used and renewed periodically.

Trade secrets cover any information a firm may have-including formulae, devices, methods, techniques, processes, etc.- that confers to this firm an advantage over competitors from not being generally known. For trade secret protection to apply, the general requirement is that reasonable efforts be undertaken to maintain secrecy. More specifically, protection is extended against another party's discovery by inappropriate means, but a trade secret offers no protection against independent discovery or reverse engineering. In the United States, trade secret protection is rooted in state law, so that the scope of protection may vary across states.

The first law that granted exclusive (but time-limited) rights to makers of inventions appears to have been implemented by the Republic of Venice in 1474. An important antecedent to U.S. legislation is the 1624 English statute of monopolies, which limited the power of the Crown to grant monopolies. In curtailing such an abused privilege, an 
exception was made for monopolies granted for "manners of new manufacture." The U.S. patent law is rooted in the Constitution, Article 1, which established that "Congress shall have the power ... to promote the progress of science and useful arts by securing for limited times to authors and inventors the exclusive right to their respective writing and discoveries." The first attempt to implement this principle in the United States was with the 1790 U.S. Patent Act, subsequently amended, extended, and consolidated several times. The bulk of current U.S. legislation dealing with IPRs originated with the Patent Act of 1952.

U.S. patent law only applies within the United States, and each nation essentially grants its own patents. An important exception is the European Patent Office (EPO), which came into existence in 1977 and grants European patents. As compared with the United States, the EPO patent procedure differs slightly on the determination of novelty (there is not a one-year grace period on published material, for example, and there are no geographical limitations on the identification of admissible prior art) and entails a somewhat more restrictive definition of what is patentable. International treaties and conventions provide a degree of international cooperation. The Paris Convention for the Protection of Industrial Property, originating in 1883 and now adhered to by about 140 countries, provides that each country extends to the citizens of other countries the same IPRs available to its own citizens. It also allows for a right of priority such that upon filing in a member nation an inventor can seek, within a given time period, protection in other countries with the original filing date applying. The Patent Cooperation Treaty (PCT) came into effect in 1978 and is adhered to by about 90 countries. It facilitates filing for patent protection for the same invention in member countries by providing centralized filing and standardized application procedures. These and related treaties are administered by the World Intellectual Property Organization (WIPO), an intergovernmental organization with headquarters in Geneva, Switzerland.

Further international harmonization in this field has been achieved by the Uruguay Round of the General Agreement on Tariffs and Trade (GATT), the precursor to the current World Trade Organization (WTO), which included an Agreement on Trade Related Intellectual Property Issues (TRIPS). This 1994 agreement provides for national treatment 
and most-favored-nation treatment on matters of patents, trademarks, and copyrights. It limits national discretion on what is patentable, limits compulsory licensing, mandates uniform or minimum protection terms (such as the 20-year term for patents), and sets out conditions for exceptions to standard practice. One such exception relates to inventions of plants and animals or essentially biological processes: such innovations can be deemed not patentable by member countries, but in such a case, alternative means of IPR protectionan "effective sui generis system"- -must be provided.

\section{IPRs for Agricultural and Life Sciences}

Some innovations pertaining to agriculture do not fall within the statutory domain of standard IPRs. For example, because patents are not meant to apply to "products of nature," the output of agronomic and biological research for a long time was offered a different kind of intellectual property protection. In the United States, the Plant Patent Act of 1930 provides protection for asexually reproduced plants. The exclusion of sexually reproduced plants from this protection was due to the assumption that sexually reproduced plants could not be propagated true-to-type. Plant patents differ from utility patents in a number of ways: they do not require the extensive detailed description demanded of utility patents, and they are limited to a single claim (whereas a utility patent offers claims to multiple variations of the same invention). Intellectual protection for plants that are sexually reproduced (by seed) or tuber-propagated is offered by the 1970 Plant Variety Protection Act in the form of plant variety protection (PVP) certificates. These certificates are not patents-they are issued by the United States Department of Agriculture (USDA) rather than the PTO_-but share many similarities with patents. Varieties claiming a protection certificate must be new and must satisfy requirements of distinctiveness, uniformity, and stability. The protection offered by PVP certificates is similar to that offered by utility patents (including a standard 20-year term) with two qualifications. First, there is a "research exception"; that is, protected varieties can be used by others for research purposes (e.g., to develop other new varieties). Second, there is a "farmer's privilege"; that is, seed of protected varieties can be saved by farmers for their own replanting (but farmers are prohibited from reselling protected 
seeds). Many other countries implement "breeders' rights" similar to those defined in the United States by PVP certificates, and such provisions are subject to an international harmonization through the International Union for the Protection of New Plant Varieties (known as UPOV, after its French acronym). The latest UPOV convention (1991) allows countries to provide protection for new varieties with both PVP certificates and utility patents, and it allows (but does not require) countries to permit the farmer's privilege exception just discussed.

A crucial development that affects the patentability of discoveries concerning life forms is the 1980 U.S. Supreme Court decision in Diamond v. Chakrabarty. Chakrabarty, working for General Electric, had succeeded in inserting plasmids into a Pseudomonas bacterium that enabled it to degrade oil, but he had been denied a patent on the grounds that this discovery was outside the statutory subject matter envisioned by patent law. In the landmark Diamond v. Chakrabarty, the Supreme Court found that biological material is patentable if obtained by an essentially nonbiological process (i.e., through human intervention). In fact, the Court held that the U.S. Congress intended the statutory subject matter of patents to "... include anything under the sun that is made by man." A broad interpretation of this ruling was affirmed in a 1985 decision involving a tryptophanoverproducing mutant of corn (Ex parte Hibberd), whereby the PTO ruled that plants can be patented (even though other forms of IPRs are available for plants). Utility patents for plants have found widespread use in the commercialization of transgenic crops, a notable early achievement of biotechnology, including Bt-cotton (resistant to bollworm infestation), Roundup-ready soybeans (tolerant to Roundup, a post-emergence herbicide), and Bt-corn (resistant to the European corn borer). Similarly, it was determined that other nonhuman multicellular organisms, including animals, could be patented (the first U.S. animal patent, pertaining to the "Harvard oncomouse," was issued in 1988).

The U.S. approach in patenting biological material is followed, to some extent, in other developed countries. But the European Patent Office (EPO), for example, is explicitly forbidden by its statute to grant patents of new animal or plant "varieties" (interpreted as narrower partitions than species). Oddly enough, however, it seems that the prohibition may not apply if the claim is for a broader taxonomic group (e.g., a 
species). In any event, such a provision still allows biological inventions to be patentable as long as they are not merely the result of "essentially biological" processes (i.e., natural phenomena such as crossing and selection). Specifically, patenting of "genes" or DNA fragments in Europe is admissible, essentially as in the United States and Japan; current practice treats the nucleotide sequence comprising a gene as it would any other complex chemical structure for the purpose of patenting. Patents are usually granted for a "purified" or "isolated" sequence (such as cloned DNA) that is in a form not found in nature per se. The standard patent requirements apply: an inventive step must be clear, novelty and enablement must hold, and specific and substantial utility must be shownfor example, use of the genetic information in a probe to diagnose a specific disease. But it should be added that some patent laws provide for ethical exceptions to the granting of patents. For example, European patents cannot be granted on inventions whose exploitation would be contrary to morality or public order. Whether such exceptions will have any relevance to the patenting of genes is, at present, moot.

To protect innovations in the life sciences that are relevant to agriculture, the current trend is for patents to assume more and more importance, relative to breeders' rights. In addition to this increased relevance of utility patents for agriculture, trade secrets law offers further protection of intellectual property that is relevant to plants. This is particularly important for hybrid varieties (virtually all corn, for example), where commercialized $F_{1}$ seeds ensure hybrid vigor only for the first generation of plants. In this case the valuable "information" is in the parent lines, which typically are not commercialized and which, as demonstrated by a few recent U.S. court cases, can be effectively protected by trade secrets law.

\section{Why Intellectual Property Rights?}

Although the analogy suggested in the introduction (intellectual property is just another form of private property) is appealing, an explicit substantiation is desirable. There are two broad distinct but related justifications for IPRs. From one perspective, IPRs can be considered a system of rewards; if by hard work and ingenuity someone creates something of value, then she deserves just compensation for the results of her 
efforts, and it should be immaterial whether the result of such efforts is a tangible output (i.e., a bushel of wheat) or an intangible one (i.e., a new method on how best to produce a bushel of wheat). As a report leading up to the adoption of the French Patent Law of 1844 put it, "Every useful discovery is ... the presentation of a service rendered to Society. It is, therefore, just that he who has rendered this service should be compensated by Society that receives it." The emphasis here is on the moral right of the discoverer, a viewpoint that is indeed well captured by the French wording for the concept of copyrights: droit d'auteur (literally, author's rights).

Alternatively, IPRs can be considered a system of incentives: IPRs are seen as desirable to stimulate and bring forth innovations that would not otherwise take place. In fact, this seems to be a major motivation for the U.S. patent law, as the aforementioned wording of Article 1 of the U.S. Constitution suggests. To a certain extent, these two rationalizations of IPRs stem from seeing the innovation from a different time perspective. Viewing IPRs as a system of rewards retains its logic ex post, when the innovation is available, whereas the emphasis on the incentive role of IPRs is most compelling from an ex ante perspective, when the innovation is still a random event and the probability of a successful discovery can be affected by investing resources and efforts. But the two distinct rationalizations for IPRs are obviously related, because it is the ex post reward that provides the ex ante incentive.

The modern perspective on the rationale for IPRs focuses on their incentive role, and clearly it is this role that is of interest from an economic point of view. In a nutshell, the economic argument here stresses the information content of new knowledge and innovations (new products, new processes). Information is a peculiar good in that it is typically very cheap to reproduce, regardless of how costly it was to produce it in the first place, and thus innovations are vulnerable to copying and imitation. Therefore, in economic terms, knowledge has the attributes of a "public good.” Absent IPRs, private producers of knowledge will not be able to appropriate the value of their work fully (or even measurably), and this nonappropriability of benefits tends to lead to underproduction of new ideas and new technologies in a private economy. A well-defined (and enforceable) allocation of property rights on new discoveries can address this externality 
problem and in principle can alleviate the economic consequences due to this market failure. An additional benefit often attributed specifically to patents is related to the disclosure requirement. In most countries patents are now disclosed at the time of granting or 18 months after the filing date, whichever comes first (an inventor filing in the United States can opt out of this requirement by foregoing the possibility of filing overseas, in which case public disclosure takes place with the granting of the patent). This disclosure is held to contribute to a desirable dissemination of scientific and technical information, allowing other inventors to avoid duplicating existing discoveries and making it easier to develop further innovations that build on the known state of the arts (possibly by "inventing around" a patent as well).

\section{Some Economics of IPRs}

As the foregoing illustrates, methods of asserting IPRs provide a potentially quite useful role by being able to mitigate the effect of a very real market failure. The problem is that real-world IPR mechanisms, such as patents, represent "second-best" solutions. The question then arises as to whether such second-best solutions do indeed improve over the benchmark of no IPRs and whether the current real-world mechanisms to implement IPRs can themselves be improved upon.

\section{Benefits and Costs of IPRs}

Patents are perhaps the prototypical instruments for the assertion of IPRs, and the economics of IPRs can be well articulated by considering patents explicitly. Recall that a patent confers to its holder the right to exclude others from making, using, or selling a product or process for a limited time (for most countries this period is now 20 years from the date of filing). The expression "right to exclude" is critical here. A patent is not a necessary condition for the "right to make, use, and/or sell" anything (a prerogative that citizens ordinarily already have); and a patent does not provide a sufficient condition for that right either (if pre-existing rights to others or government regulation legally prevent it). But having understood that, and given some ancillary conditions on the availability of legal enforcement, from an economic perspective the reward that a patent gives essentially is the right to be a monopolist for the innovation for a limited time. 
Suppose that a firm obtains a patent for a new product, which can then be manufactured at a constant unit cost $c$. For simplicity's sake, think of the life of the patent as a single period, during which the demand for the new patented product is $D(p)$, where $p$ is the price charged for the new product. This demand can arise from consumers if the innovation is a final product, or from other firms if the innovation is an intermediate input. We can safely assume that if $p$ is large enough, no one will want to buy the new product; i.e., there exists a price $\bar{p}$ such that $D(p)=0$ for all $p \geq \bar{p}$. To make the problem interesting it must be that $c<\bar{p}$. At prices below $\bar{p}$, more and more of the new product will be demanded; i.e., $D(p)>0$ and $D^{\prime}(p)<0$ for all $0 \leq p<\bar{p}$. Ex post efficiency requires that the new product be priced at marginal cost, i.e., that $p=c$. Whereas this outcome would be guaranteed by a competitive market setting, the firm holding the patent will find it optimal to behave otherwise. With $p=c$, in fact, the firm makes zero profit. Raising the price above the marginal cost $c$ allows positive profits, although it reduces demand [because $D^{\prime}(p)<0$ ], but at $p=\bar{p}$ the firm again would make zero profits. Thus there will be (at least) an optimal price $p^{*}$, satisfying $c<p^{*}<\bar{p}$, which maximizes the innovator profits.

Whereas this pricing is optimal from the innovating firm's point of view, the quantity of new product is inefficiently low from a social point of view [i.e., $D\left(p^{*}\right)<D(c)$ ]. This brings to the fore a fundamental trade-off of any IPR system: the balancing between the benefits of encouraging additional innovative activities and the costs of foregoing the competitive provision of some goods and services. Ex post (that is, given that an innovation is available) a monopoly is bad from society's point of view because it restricts uses of the new product or process, relative to the competitive provision of the innovation. But the profit opportunity created by the monopolistic control of the innovation may be a powerful ex ante incentive, presumably enough to motivate research and development (R\&D) investments that would otherwise be neglected. 


\section{The Scope of Patent Protection}

The foregoing discussion illustrates a fundamental question that affects real-world mechanisms for IPRs: what is the optimal degree of intellectual protection? Taking once again the specific case of patents, the question boils down to the optimal "length" of the patent rights and the permissible scope of the monopoly rights granted by the patent (the "breadth" of the patent). For a given breadth of the patent, a longer life for a patent means higher expected profit for the innovation. Thus, for a given patent breadth, its optimal length from society's perspective should be the period of time that is just long enough to bring about the innovation (such that present value of expected private benefits to would-be innovators equals the present value of expected costs). This consideration immediately suggests that the optimal patent length is likely to be innovation-specific, and thus the onesize-fits-all patent length (20 years from filing) is suboptimal. Roughly speaking, a uniform patent length provides too much protection for "easy" innovations (those that would have been pursued even with a shorter patent period), thereby creating unnecessary efficiency losses, whereas it provides too little protection for "difficult" innovations, such that some research projects that are socially desirable are not undertaken.

Increasing the range of products over which a given patent is given exclusive rights—i.e., increasing the patent's breadth—clearly increases the expected profitability of the patent. Unlike its length, patent breadth is, to a certain extent, endogenous (it depends on the claims put forth by the patentee) and also is a feature over which the patent office has some discretion (at the examination stage). What is the optimal patent breadth? The "prospect theory" of patents, for instance, argues that patent protection in general should provide broad protection. The analogy here is with rights to mineral claims for a prospecting firm. By granting exclusive rights to innovations that arise from an invention, broad patent rights promote the efficient exploitation of an invention. But one should not conclude that broader patents necessarily induce more research. The problem is that, ex ante, a potential inventor needs to consider the possibility of discovering something that infringes on existing patents. The broader the patents, the greater the risk of such a possible unwanted infringement, and this possibility can discourage $R \& D$ investments. 
In any case, it is clear that patent breadth can substitute for patent length and that the degree of substitutability depends on the nature of the innovation. Specific conclusions about optimal patent length and breadth are therefore sensitive to the way one chooses to model the innovation process. But concerns about exceedingly broad patents being granted are common, particularly in recent innovation fields such as biotechnology and so-called business methods. As for the latter, concerns have also been raised about whether these business methods innovations live up to the novelty and nonobviousness standards that one expects from patented inventions.

\section{Patent Races}

As noted earlier, IPRs can be interpreted as a way to correct a market failure concerning the private appropriability of the economic benefits of innovations. The presumption is that, absent IPRs, economic agents will not have sufficient incentives to invest in R\&D activities, and consequently society will not enjoy enough innovations. The term of comparison here is usually the "socially optimal" level of R\&D activities, which one can define (at least conceptually) taking into account the overall expected benefits brought about by an innovation, as well as the costs of R\&D projects. This firstbest solution typically cannot be achieved by a decentralized market system, for lack of incentives and coordination mechanisms (the "market failure" predicament), and it cannot be achieved by a centralized government either, for lack of information and implementation mechanisms. Given these benchmarks, a given IPR system (say a patent system) is likely to increase private investments toward the first-best (social optimum) level, relative to a situation without IPRs.

Because IPRs typically provide only imperfect ways of privately appropriating social benefits from innovations, the hypothesis would seem to be that, even with an IPRs system, too few resources are privately invested in R\&D. But we must consider that there is always the possibility of entry in the innovation industry. A patent, for example, creates an ex post rent position for the patent holder, and it is the quest for this ex post rent that provides the $R \& D$ incentive. In general, it will be possible (and likely) for more than one firm to be pursuing the same research result in a "patent race." The race to patent tends to dissipate the expected rent from patenting and to increase aggregate $\mathrm{R} \& \mathrm{D}$ 
investment (in a fashion akin to the "common pool" problem of competitive fishing in an open access fishery).

Such an increase in R\&D investment is usually desirable, given the underinvestment connotation of the benchmark without patents, in that it can reduce the (stochastic) time required for achieving a given innovation. But firms engaged in a patent race collectively may invest more than is socially desirable. Also, firms engaged in a patent race tend to choose research strategies that are too risky. (As the race is essentially a winner-takes-all contest, there is a clear payoff to being first, but the penalty for losing does not depend on how far behind one ends up.) Also, firms will tend to choose research projects that from a social perspective display too much correlation (i.e., there is too much duplication of research efforts). To illustrate this last point, suppose that it is socially desirable for a particular firm to choose a research direction very different from that of competitors (because that would increase the probability of someone being successful). But an individual firm may not want to follow such a (socially optimal) strategy because by doing so it would increase the probability that a competitor is successful in instances when the firm in question is not.

\section{Cumulative Innovations}

Questions about the excessive scope of IPRs are particularly acute from a dynamic perspective, when inventions are seen as input in further inventions and innovations. For example, an innovation could be mostly useful as a research tool in other R\&D activities (e.g., genomic discoveries to be used in new pharmaceutical developments). IPRs on earlier innovations raise the cost of subsequent innovators (who must buy access to the earlier patented innovation, say), and this may stifle socially desirable innovation. Thus, one may argue in favor of narrow IPR protection to reduce the cost of later innovations. On the other hand, it is important that incentives are sufficient to bring about the earlier innovation in the first place, and that requires transferring some surplus generated by later innovations to the first innovator. Earlier innovators will typically have too little incentive, and increased protection for earlier innovations (by means of a longer patent life, for example) is generally desirable. The argument here relies on the insight that earlier innovators with broader IPRs will have more incentive to bring about profitable 
later innovations, possibly through licensing to third parties. But the role of licensing in this setting is not straightforward. If licensing is to take place ex post (after the second innovator has sunk the derivative product's R\&D costs), there may not be enough incentives to bring about the second-generation innovation. By contrast, ex ante licensing can increase the likelihood that second generation $R \& D$ projects are pursued, but they may still fail to transfer enough surplus to the first-generation inventor to provide enough incentive for this first invention to actually take place.

A cumulative research problem also arises in the so-called quality ladders case, when innovations represent successive improvements in the same product market. A new generation of the product effectively terminates the productive life of an earlier innovation. In this setting it can be shown that some leading breadth for patents is crucial to providing enough innovation incentive, which can be directly related to the patentability requirement of the law. Leading breadth is defined by the set of new products (possibly yet to be invented) that, while superior, would be found to infringe the patent claims of the current product. In this sequential setting, broader protection is useful because it accelerates the pace of innovation, but broader protection again entails efficiency losses because it consolidates market power along the quality ladder. Current USPTO practices address the patentability requirement by the novelty requirement, where both specific and substantial utility are required at the examination stage. In U.S. case law this requirement is upheld by the so-called doctrine of equivalents, which asserts that a new product that is outside the stated claims of an existing patent could still infringe on this patent if it is essentially an equivalent product. By contrast, Japan's patent system is widely faulted with having a very weak novelty requirement.

Economic considerations are somewhat different when innovations are sequential and research projects are complementary (in the sense that increasing the number of firms involved in an R\&D project raises the probability that someone will succeed). This hypothesis of complementarity by itself does not change standard results if the setting is a static one; absent IPRs, the possibility of imitations creates an incentive failure and there may be underinvestment in innovation activities. Hence, establishing IPRs through a patent system may be welfare improving. But in a dynamic framework there are greater 
incentives for R\&D investments, even without IPRs. This is because more firms engaged in $R \& D$ raise the probability that an innovation will be realized, and this is valuable (even if innovations are imitated) because it makes further innovations possible. It turns out that a regime without patents in this setting can bring about more innovation than a regime with patents. This insight might explain why industries such as software, computers, and semiconductors have exhibited very high rates of innovation while, for a long time, they enjoyed weak patent protection (and imitation was common).

\section{Complementary Innovations}

The cumulative nature of many discoveries assumes a particular connotation when innovations are complementary. To manufacture a complex new product (e.g., a computer chip, or a transgenic crop), it is common for firms to need a number of intermediate inputs that are patented, with such patent rights likely held by different firms. Insofar as the patented inputs are highly complementary, or even essential, in the manufacture of the new product, the suppliers of these inputs essentially hold blocking patents. The danger then is that the manufacturer becomes susceptible to hold-up by the patentees. This problem has been discussed in the context of biotechnology innovations, leading to the notion of the "tragedy of the anticommons." Tragedy of the commons generally refers to the overuse of a common property resource, and it arises because there are not enough allocated property rights. The tragedy of the anticommons situation arises because, somewhat paradoxically, there is an excess allocation of property rights (i.e., too many gatekeepers with the right to levy a tax), and this situation can lead to an underuse of the resource (in this case, the pool of knowledge).

It is clear that the hold-up problem when patented innovations are complements can be quite damaging to the functioning of the patent system. The issue here is mostly one of coordination among IPRs holders. Mechanisms that can address the hold-up problem in this setting include cross-licensing and patent pools. With cross-licensing, which can be implemented with or without license fees, two (or more) firms agree to share a subset of each other's patented technologies. This kind of arrangement is particularly attractive when the relevant patents are held by the manufacturers of the new product that needs the complementary patented inputs. Cross-licensing is apparently quite common between 
firms engaged in the design and manufacture of microprocessors, for example. A patent pool is an arrangement whereby a set of patents is licensed in a single package, for a posted fee, either by a single owner or by an entity especially set up to handle this arrangement. The obvious danger here is that, whereas the inclusion of complementary patents in the pool is justifiable by the foregoing discussion and leads to pro-competitive behavior, the inclusion of substitute (rival) patents in the pool could be a means to implement collusion and exacerbate noncompetitive behavior. Patent pools, therefore, can pose antitrust issues. Another way to reduce the fragmentation of patent ownership is through mergers and acquisitions, and that, indeed, appears to be one of the driving forces behind industry consolidation in the life sciences sector.

\section{Alternatives to Patents}

From an economic perspective, the patent system represents a "second-best" solution to the market failure arising from the public good nature of knowledge. However appealing this system might seem, it is quite possible that better solutions to the problem at hand could be devised. In fact, it seems that for most of the nineteenth century the patent system was under considerable criticism by the same economic profession that now provides the most valuable insights in its defense. As noted, the ex post inefficiency of the patent system is viewed as the necessary downside to providing enough inducement to undertake desirable R\&D projects. The size of the inducement depends on the length and breadth of the patent right. Ideally, such an inducement should be proportional to the cost of the R\&D project, which means that the length and breath of a patent should be tailored to each particular innovation. In addition to the cost of the project, such a tailored patent should also reflect the particular market conditions of the new product and/or process. Clearly, the patent system does not do that (and arguably cannot do that: R\&D cost, for example, would be difficult for a patent office to verify).

Given that the patent system is fraught with such shortcomings, alternatives that have been considered include rewards or prizes, procurement contracts, and patent buyouts. For the economic analysis of such alternatives, it is crucial to explicitly account for the fact that researchers and the government operate in an asymmetric information setting. 
With the reward system, the government specifies a fixed sum of money for a welldefined research goal and then awards this "prize" to the first firm to achieve the desired result. The difficulty with implementing such a system is quite apparent: to be effective, the government must know about the feasibility of various research projects, as well as be able to assess the demand for various potential innovations. But firms are likely to be better informed than the government on such matters, and a decentralized solution such as the patent system may be superior. With the procurement system, the government picks the firms that will be involved in the research project and specifies the terms of the project (such as expected research output and financial rewards) in a binding contract. Unlike the prize system, this method can eliminate unwanted duplication of research efforts. But again, for this system to be efficient, the government must be quite knowledgeable about the costs and benefits of research ventures. This issue may be less problematic when the government is the only intended customer of the innovation, as happens, for example, with research related to national defense.

Patent buyouts do presuppose a functioning patent system, so in that sense they are not alternative to it. With this scheme the government offers to buy awarded patents, at their private value, say, and then puts the new technology in the public domain. In principle this model could eliminate some shortcomings of the patent system, including the ex post inefficiency due to the monopolistic pricing of patented innovations. But, clearly, a successful implementation of this system relies on the (possibly unwarranted) presumption that the government has the required kind and level of information.

\section{Some Open Policy Issues}

The current system can point to a steep increase in the number of patents applied for and awarded in many fields, and to a general trend toward strengthening IPRs throughout the world. But despite this seeming success, it is fair to say that there is some unease about the status quo. Although a consideration of empirical studies is outside the scope of this review, one may note that the empirical evidence is not clear-cut on whether (and perhaps more important, on when) the economic benefits of IPRs outweigh the costs. The 
patent system, in particular, has been the object of considerable criticism, and calls for reform are common.

\section{Administrative and Transaction Costs}

As much as the standard case in favor of IPRs seems compelling, property rights do not work simply by fiat. Rights must first be allocated, the boundaries of these rights must be delineated, and violations must be detected and punished. Furthermore, explicit transactions are often necessary to use resources protected by IPRs. These administrative and transaction costs do add up, and it is quite possible that, in some specific cases, common property may be more efficient, even ex ante, than private property.

The filing costs and legal fees required to obtain a patent are generally substantial. In the United States they are estimated at $\$ 10,000-\$ 25,000$, per patent. Filing and renewal fees can be even higher in Europe. Enforcement of patents can be considerably more taxing. Litigating a patent infringement case in the United States can easily cost $\$ 1.5$ million per side. It is estimated that about one percent of all patents are litigated in the United States, although there are sizable differences across fields (the proportion of litigated biotechnology patents, for example, is reportedly much higher). In any case, these are not small numbers, considering that many patents turn out not to have economically viable utilization. The fear is that the high cost of asserting and enforcing patent rights can severely damage the value of these instruments as incentives for innovation. And concern has also been voiced that, with such an apparent large cost of this mode of IPRs, protection is skewed in favor of large firms.

It is unclear what might be done to reduce the transaction costs associated with the patent system. But it certainly seems that the U.S. system relies heavily on very expensive legal litigation procedures to determine the validity and scope of patents. This situation might be improved if the United States were to adopt an opposition system such as that employed in Europe and Japan, because opposition is far less costly than litigation. With the European system, for example, third parties can file an opposition within nine months of the grant date of a patent. The procedure is adversarial and allows third parties to introduce relevant evidence, including the testimony of experts. Such a system would seem particularly suited to weed out bad patents, such as those claiming 
unwarranted breadth and/or lacking true novelty (standard charges against many recent business methods patents). A fair number of the patents granted in Europe are opposed (about 6 percent, with this rate exceeding 8 percent for biotechnology and pharmaceutical patents), and about one-third of the opposed patents result in revocation. By contrast, the U.S. re-examination procedure does not seem to allow third parties to effectively challenge patents. An added bonus of the European opposition system is that it must take place (if at all) very early in the patent life, thereby eliminating considerable uncertainty for everyone involved (inventors as well as potential infringers). Another change that likely would remove some uncertainty from the U.S. patent process is a move to a firstto-file priority (the argument in favor of keeping the current first-to-invent priority system is that it may be more desirable for small inventors).

\section{Patenting by Public Institutions}

An important argument in support of the patent system is to create incentives for private investment in innovative activities. Public institutions, such as universities, would seem not to need that incentive, yet in recent times we have seen a marked increase in the propensity to patent inventions by universities (especially in the United States). This development is often attributed to the Patent and Trademark Laws Amendments of 1980, commonly known as the Bayh-Dole Act. The main elements of this reform were to allow universities and other entities to patent, retain title to, and commercialize their federally funded inventions, and to allow federal agencies to grant exclusive licensing for their inventions. The goal was to promote "technology transfer." One of the presumptions was that many discoveries produced by publicly funded $R \& D$, and in the public domain, were not being used in technological developments (presumably because without exclusive licensing, firms would not be interested in expensive development work required to transform an invention into a new product). Actually, little evidence seems to corroborate this belief. As for whether the Bayh-Dole Act is actually responsible for the rise of university patenting, the evidence is not conclusive, partly because enactment of the Bayh-Dole Act was coincidental with a broader U.S. policy shift toward stronger IPRs protection (including the 1982 creation of the Court of Appeals for the Federal Circuit, which turned out to strengthen the rights of patent holders). The growth of biomedical 
and biotechnology research, together with the 1980 Chakrabarty ruling discussed earlier, also contributed to positioning a larger number of university discoveries into the patentable set.

Regardless of what is at the root of the recent trend toward increased university patenting, concerns are often expressed about the dangers of overprivatization of the "intellectual commons," especially in sectors that are highly science-intensive, such as the biotechnology industry. A separate concern is that the emphasis on patenting may bias the public institutions' $R \& D$ activities away from their traditional emphasis on "basic research" and toward more "applied research," although some preliminary evidence is not supportive of this worry.

\section{Conclusion}

Patents and other IPRs are intimately connected with the innovation process, the powerful engine for economic growth. Patents were instrumental in bringing about crucial technical improvements in the industrial revolution, and, indeed, IPR protection has been claimed as the single strongest explanation for industrial development by some models of endogenous growth. Central concerns about IPR systems include the mode and degree of protection that should be accorded to inventors and creators of intellectual advancements. Private property of intellectual assets carries both benefits and costs to society. The IPR system that has evolved over the centuries can be credited with many achievements. But change, in a broad sense, is also inevitably associated with innovations. The relentless pace of scientific and technological advancements not only makes old products less appealing and old techniques obsolete, but it can similarly threaten with obsolescence seasoned IPR institutions. Continued monitoring of the efficiency of existing IPR systems, with attention to the economic trade-offs involved, is warranted. 


\section{References $^{1}$}

Arrow, K.J., 1962, "Economic Welfare and the Allocation of Resources for Inventions," in The Rate and Direction of Inventive Activity: Economic and Social Factors, ed. R.R. Nelson, Princeton University Press. [This paper presents an insightful economic analysis of invention and research as production of information.]

Barton, J.H., 1998, “Acquiring Protection for Improved Germplasm and Inbred Lines,” in Intellectual Property Rights in Agricultural Biotechnology, eds. F.H. Erbisch and K.M. Maredia, CAB International. [This paper provides a concise discussion of IPR issues for traditional breeders.]

Besen, S.M., and L.J. Raskind, 1991, "An Introduction to the Law and Economics of Intellectual Property," Journal of Economic Perspectives, 5, 3-27. [This article gives a brief review of the main legal and economic features of IPRs.]

Bessen, J., and E. Maskin, 2000, "Sequential Innovation, Patents, and Imitation," MIT Department of Economics, Working Paper No. 00-01, January. [This paper presents an economic model of patents when innovations are both sequent.ial and complementary.]

Dasgupta, P., and E. Maskin, 1987, “The Simple Economics of Research Portfolios,” Economic Journal, 97, September, 581-95. [This article provides some basic insights into the economics of patent races.]

Dutton, H., 1984, The Patent System and Inventive Activities During the Industrial Revolution 1750-1852, Manchester, UK: Manchester University Press. [This book provides evidence on the incentive role of patents in a critical period of economic growth.]

Friedman, D.D., W.M. Landes, and R.A. Posner, "Some Economics of Trade Secret Law," Journal of Economic Perspectives, 5, 61-72. [This article provides an introduction to the economics of trade secrets.]

Gilbert, R., and C. Shapiro, 1990, “Optimal Patent Length and Breadth,” Rand Journal of Economics, 21 (Spring), 106-112. [This paper develops an economic model to analyze the trade-offs of patent length and breadth.]

Green, J., and S. Scotchmer, 1995, “On the Division of Profit in Sequential Innovations," RAND Journal of Economics, 26, 1, 20-33. [This article provides an economic analysis of sequential innovations.]

Heller, M.A., and R.S. Eisenberg, 1998, “Can Patents Deter Innovations? The Anticommons in Biomedical Research," Science, 280, 698-701. [This article argues that too much privatization of intellectual property may adversely affect innovation.]

Jaffe, A., 2000, “The U.S. Patent System in Transition: Policy Innovation and the Innovation Process," Research Policy, 29, April, 531-558. [This article discusses some recent policy issues related to the working of the patent system.]

\footnotetext{
${ }^{1}$ The (somewhat unusual) format used here is to comply with the guidelines of the Encyclopedia of Life Support Systems.
} 
Kitch, E.W., 1977, "The Nature and Function of the Patent System," Journal of Law and Economics 20, 265-290. [This article introduces the so-called prospect theory of patents.]

Klemperer, P., 1990, "How Broad Should the Scope of Patent Protection Be?" RAND Journal of Economics, 21 (Spring), 113-130. [This article analyses the issue of optimal length and breadth of a patent.]

Kremer, M., 1998, "Patent Buyouts: A Mechanism for Encouraging Innovation,” Quarterly Journal of Economics, 113, November, 1137-67. [This article discusses how buyouts of patents can increase economic welfare.]

Landes, W.M., and R.A. Posner, 1989, “An Economic Analysis of Copyright Law," Journal of Legal Studies, 18, 325-363. [This article provides an authoritative study of the economics of copyrights.]

Machlup, F., and E. Penrose, 1959, "The Patent Controversy in the Nineteenth Century," Journal of Economic History, 10, May, 1-29. [This article gives a historical perspective on the economic thinking about patents.]

Maskus, K., 1998, “The International Regulation of Intellectual Property,” Weltwirtschaftliches Archiv, 134, 186-208. [This article includes a discussion of the TRIPS agreement and some evidence on its economic effects.]

Merges, R.P., and R.R. Nelson, 1990, "On the Complex Economics of Patent Scope," Columbia Law Review, 90, 839-916. [This article studies the appropriate breadth of patents.]

Merges, R.P., 1997, Patent Law and Policy: Cases and Materials, 2nd ed., Charlottesville, VA: Reed Elsevier, Inc. [This book provides an exhaustive treatment of U.S. patent law.]

Merges, R.P., 1999, “As Many as Six Impossible Patents Before Breakfast: Property Rights for Business Concepts and Patent System Reform," Berkeley Technology Law Journal, 14, 577-615. [This article discusses legal and economic issues of patenting business methods.]

Mowery, D.C., R.R. Nelson, B.N. Sampat, and A.A. Ziedonis, 2001, "The Growth of Patenting and Licensing by U.S. Universities: An Assessment of the Effects of the Bayh-Dole Act of 1980," Research Policy, 30, 99-119. [This article studies the roots of increased U.S. university patenting.]

Nordhaus, W., 1969, Invention, Growth and Welfare: A Theoretical Treatment of Technological Change, Cambridge, MA: MIT Press. [This book presents a neoclassical model of inventions, including a seminal analysis of the economics of patents.]

O’Donoghue, T., 1998, “A Patentability Requirement for Sequential Innovations,” RAND Journal of Economics, 29, Winter, 654-679. [This article presents a study of sequential innovations in a quality ladders framework.]

Wright, B., 1983, "The Economics of Invention Incentives: Patents, Prizes, and Incentive Contracts," American Economic Review 73, 691-707. [This article provides an insightful study of the economics of patents, and other alternative instruments, in an asymmetric information context.] 